\title{
Contributions of the $\mathrm{Hfq}$ protein to translation regulation by small noncoding RNAs binding to the mRNA coding sequence
}

\author{
Zuzanna Wroblewska ${ }^{\varpi}$ and Mikolaj Olejniczak ${ }^{\bowtie}$ \\ Department of Biochemistry, Institute of Molecular Biology and Biotechnology, Faculty of Biology, Adam Mickiewicz University in Poznań, \\ Poznań, Poland
}

\begin{abstract}
The bacterial Sm-like protein $\mathrm{Hfq}$ affects the regulation of translation by small noncoding RNAs (sRNAs). In this way, Hfq participates in the cell adaptation to environmental stress, regulation of cellular metabolism, and bacterial virulence. The majority of known sRNAs bind complementary sequences in the 5'-untranslated mRNA regions. However, recent studies have shown that sRNAs can also target the mRNA coding sequence, even far downstream of the AUG start codon. In this review, we discuss how Hfq contributes to the translation regulation by those sRNAs which bind to the mRNA coding sequence.
\end{abstract}

Key words: Hfq, sRNA, mRNA, coding sequence, RNase E, ribosome Received: 06 June, 2016; revised: 11 October, 2016; accepted: 13 October, 2016; available on-line: 23 November, 2016

\section{INTRODUCTION}

The Sm-like protein $\mathrm{Hfq}$ is a global regulator, which mediates the interactions between trans-encoded small noncoding RNAs (sRNAs) and their mRNA targets (Waters \& Storz, 2009; Updegrove et al., 2016). Hfq is conserved in more than half of known bacterial species, but its role in the interactions with small RNAs has been most thoroughly explored in the Escherichia coli and Salmonella typhimurium enterobacteria (Vogel \& Luisi, 2011). sRNAs exert their control of gene expression by binding to partly complementary sequences in the target mRNAs (Melamed et al., 2016), which can lead to changes in the access of the ribosome to the mRNA or can affect the mRNA stability (Waters \& Storz, 2009). sRNAs participate in regulation of the cell's adaptation to changes in the environment, including regulation of the protein composition of the cell membrane (Chao \& Vogel, 2016; Parker \& Gottesman, 2016), metabolism of nitrogen compounds (Hao et al., 2016), sugar metabolism (Beisel \& Storz, 2011), regulation of extrachromosomal DNA elements (Cech et al., 2014; Papenfort et al., 2015), control of transcription and RNA decay (Lalaouna et al., 2015; Fontaine et al., 2016; Lee \& Gottesman, 2016), biofilm formation (Jorgensen et al., 2013), and the interactions with the host organism during infection (Chao \& Vogel, 2010; Papenfort \& Vogel, 2014; Kakoschke et al., 2016).

The Hfq protein has a shape of a homohexameric ring with three distinct RNA binding sites on its surface, which allows it to simultaneously interact with several RNA molecules (Schumacher et al., 2002; Mikulecky et al., 2004; Link et al., 2009; Sauer et al., 2012). The site located on the distal face of the Hfq ring preferential- ly binds adenosine-rich sequences or the repeated trinucleotide ARN motifs (adenosine, purine, any nucleotide) that are mainly found in mRNAs (de Haseth \& Uhlenbeck, 1980; Mikulecky et al., 2004; Soper \& Woodson, 2008; Salim et al., 2012; Ellis et al., 2015; Wroblewska \& Olejniczak, 2016). The site on the proximal face is recognized by uridine-rich sequences, such as the 3'-terminal sRNA tails arising from the Rho-independent terminators of transcription (Otaka et al., 2011; Sauer \& Weichenrieder, 2011; Morita et al., 2015). The third RNA binding site is located on the rim of the Hfq ring (Sauer et al., 2012). The positively charged amino acids on the rim are essential for the influence of Hfq on RNA annealing (Panja et al., 2013; Zheng et al., 2016), while the adjacent negatively charged residues on the proximal face contribute to the specificity of Hfq binding to different RNA targets (Panja et al., 2015). Although RNA molecules bind to Hfq with tight, sub-nanomolar affinities, they are rapidly recycled in competition with other RNA targets of Hfq (Fender et al., 2010; Olejniczak, 2011; Malecka et al., 2015; Santiago-Frangos et al., 2016). The multiple RNA binding sites of $\mathrm{Hfq}$ allow it to use different binding modes in interactions with complementary sRNA and mRNA molecules to facilitate their pairing (Zhang et al., 2013; Schu et al., 2015).

Many of the Hfq-dependent small RNAs affect translation initiation by pairing in the area of the ribosome binding site in the 5'-untranslated regions of the mRNA molecules. Hfq contributes to this regulation in different ways. For example, the role of Hfq in the positive regulation of the rpos mRNA translation is to rearrange the structure of this mRNA to facilitate binding of the DsrA sRNA to the 5'-UTR (Soper \& Woodson, 2008; Soper et al., 2010). The distortion of $r p o S$ mRNA structure is induced by $\mathrm{Hfq}$ binding to an $(\mathrm{ARN})_{4}$ sequence, and the following binding of DsrA sRNA allows to shift the equilibrium between the ribosome-accessible and inaccessible conformations of this 5'-UTR leading to activation of the rpoS mRNA translation (Lease \& Woodson, 2004; Soper \& Woodson, 2008; Soper et al., 2011; Peng et al., 2014a; Peng et al., 2014b). In the negative regulation of translation by sRNAs binding to the 5'-UTR of mRNA, Hfq also often contributes to sRNA annealing to mRNA (Moller et al., 2002a; Zhang et al., 2002; Geissmann \& Touati, 2004). However, other modes of Hfq action are also possible. The Hfq protein is recruited by Spot42

e-mail: z.urb@amu.edu.pl (ZW), mol@amu.edu.pl (MO) Abbreviations: ARN, a trinucleotide sequence consisting of adenosine, purine, any nucleotide; AU-rich sequence, adenosine and uridine-rich sequence; $\mathrm{Hfq}$, Host factor for phage $\mathrm{Q}$ beta replication; 5'-UTR, 5'-untranslated region; RIL-seq, RNA interaction by ligation and sequencing; sRNA, small noncoding RNA 
Table 1. sRNAs binding in the five-codon window of their target mRNA molecules.

\begin{tabular}{|c|c|c|c|c|c|}
\hline sRNA & $\begin{array}{l}\text { mRNA } \\
\text { (bacterial species) }\end{array}$ & $\begin{array}{l}\text { Hfq binds to } \\
\text { sRNA/ mRNA }\end{array}$ & $\begin{array}{l}\text { sRNA binding } \\
\text { site in the CDS }\end{array}$ & Hfq's role & References \\
\hline Spot42 & $\begin{array}{l}x y l F \\
(E . \text { coli })\end{array}$ & $+/+$ & $+2-+40$ & stabilizes Spot42 & $\begin{array}{l}\text { (Beisel \& Storz, 2011; Melamed et } \\
\text { al., 2016) }\end{array}$ \\
\hline RybB & $\begin{array}{l}\text { ompW } \\
\text { (S. Typhimurium) }\end{array}$ & $+/$ n.d. & $+3-+20$ & stabilizes RybB & $\begin{array}{l}\text { (Papenfort et al., 2006; Papenfort } \\
\text { et al., 2010) }\end{array}$ \\
\hline DsrA & $\begin{array}{l}\text { hns } \\
(E . \text { coli })\end{array}$ & $+/+$ & $+3-+19$ & $\begin{array}{l}\text { stabilizes DsrA, } \\
\text { translation inhibition is } \\
\text { Hfq-dependent }\end{array}$ & $\begin{array}{l}\text { (Sledjeski et al., 2001; Lalaouna et } \\
\text { al., 2015; Melamed et al., 2016) }\end{array}$ \\
\hline RybB & $\begin{array}{l}\text { ompN } \\
\text { (S. Typhimurium) }\end{array}$ & $+/+$ & $+4-+11$ & $\begin{array}{l}\text { stabilizes RybB, binds both } \\
\text { RNAs using different sites }\end{array}$ & $\begin{array}{l}\text { (Papenfort et al., 2006; Bouvier et } \\
\text { al., 2008; Sittka et al., 2008; Sauer } \\
\text { et al., 2012) }\end{array}$ \\
\hline RybB & $\begin{array}{l}\text { ompS } \\
\text { (S. Typhimurium) }\end{array}$ & +/ n.d. & $+7-+20$ & stabilizes RybB & $\begin{array}{l}\text { (Papenfort et al., 2006; Papenfort } \\
\text { et al., 2010) }\end{array}$ \\
\hline RybB & $\begin{array}{l}\text { ompD } \\
\text { (S. Typhimurium) }\end{array}$ & $+/+$ & $+10-+26$ & $\begin{array}{l}\text { stabilizes RybB, } \\
\text { accelerates RybB annealing } \\
\text { to mRNA }\end{array}$ & $\begin{array}{l}\text { (Papenfort et al., 2006; Papenfort } \\
\text { et al., 2010; Wroblewska \& Olejni- } \\
\text { czak, 2016) }\end{array}$ \\
\hline ArcZ & $\begin{array}{l}\text { tpx } \\
\text { (S. Typhimurium) }\end{array}$ & +/ n.d. & $+10-+26$ & $\begin{array}{l}\text { stabilizes ArcZ, } \\
\text { essential for translation } \\
\text { repression }\end{array}$ & $\begin{array}{l}\text { (Sittka et al., 2008; Papenfort et al., } \\
\text { 2009; Sittka et al., 2009) }\end{array}$ \\
\hline RybB & $\begin{array}{l}\text { chip } \\
\text { (S. Typhimurium) }\end{array}$ & +/ n.d. & $+12-+18$ & stabilizes RybB & $\begin{array}{l}\text { (Papenfort et al., 2006; Balbontin } \\
\text { et al., 2010) }\end{array}$ \\
\hline Spot42 & $\begin{array}{l}\text { sthA } \\
(\text { E. coli) }\end{array}$ & $+/+$ & $+15-+22$ & stabilizes Spot42 & $\begin{array}{l}\text { (Moller et al., 2002b; Beisel \& } \\
\text { Storz, 2011) }\end{array}$ \\
\hline InvR & $\begin{array}{l}\text { ompD } \\
\text { (S. Typhimurium) }\end{array}$ & $+/+$ & $+15-+65$ & stabilizes InvR & (Pfeiffer et al., 2007) \\
\hline MicL & $\begin{array}{l}\text { Ipp } \\
\text { (E. coli) }\end{array}$ & $+/+$ & $+16-+28$ & stabilizes MicL & $\begin{array}{l}\text { (Guo et al., 2014; Melamed et al., } \\
\text { 2016) }\end{array}$ \\
\hline
\end{tabular}

n.d. - no data

sRNA to the $s d h C$ mRNA ribosome binding site to inhibit protein synthesis (Desnoyers \& Masse, 2012). Hfq can also directly repress translation of other mRNAs by binding to their 5'-untranslated regions and interfering with translation initiation (Salvail et al., 2013; Sonnleitner \& Blasi 2014; Ellis et al., 2015).

The Hfq protein also plays a role in protecting bound sRNA molecules from degradation before they pair with their mRNA targets (Saramago et al., 2014). RNase E is a major enzyme responsible for RNA degradation and processing in E. coli and displays specificity towards single-stranded AU-rich sequences and 5'-monophosphorylated substrates (Saramago et al., 2014; Frohlich et al., 2016; Richards \& Belasco, 2016). However, other RNases are also involved in regulation exerted by sRNAs (Andrade et al., 2012). Beyond sRNA protection, Hfq can also contribute to sRNA-dependent mRNA decay by recruiting RNase E to mRNA (Ikeda et al., 2011).

The mRNA coding sequence can also serve as a target for regulatory small RNAs (Bouvier et al., 2008; Pfeiffer et al., 2009; Gutierrez et al., 2013; Papenfort et al., 2013; Guo et al., 2014; Bobrovskyy \& Vanderpool, 2016; Melamed et al., 2016). This is counterintuitive, because the elongating ribosome has a strong helicase activity and would be expected to unfold sRNA-mRNA complexes on its path (Takyar et al., 2005; Qu et al., 2011). However, a recent study using RIL-seq methodology revealed that the mRNA coding sequence is an important target of Hfq-bound sRNAs in the E. coli cells (Melamed et al., 2016). These data are supported by two other Hfq profiling studies, which had shown that more than a third of the identified Hfq binding sites were located in the mRNA coding sequences (Tree et al., 2014; Holmqvist et al., 2016). The mechanisms used by several of those sRNAs have already been investigated, and they are discussed here to elucidate the possible contributions of $\mathrm{Hfq}$ to the regulation of translation by small RNAs binding to the mRNA coding sequences.

\section{REGULATION IN THE FIVE-CODON WINDOW}

The region of mRNA covered by the initiating ribosome consists of about 30 nucleotides, with mRNA entering the ribosome at about 15 nucleotides from the start codon (Huttenhofer \& Noller, 1994; Yusupova et al., 2001). The sRNAs which target the 5'-untranslated region often interfere with the ribosome access to the Shine-Dalgarno sequence or the start codon. However, pairing of sRNAs to the region of the mRNA coding sequence protected by the initiation complex can also lead to translation repression (Table 1). The first described example of such regulation was the Salmonella ompN mRNA, whose translation is controlled by RybB sRNA (Bouvier et al., 2008). The results of toeprinting experiments and in vitro translation assays had shown that RybB sRNA, which binds at +4 to +11 of the ompN coding sequence, interferes with translation at the stage of initiation. Further experiments using a complementary oligonucleotide indicated that the first 15 nucleotides of the coding sequence constitute a region in which sRNA binding leads to translation repression. This region has been called a five-codon window for the mRNA translation regulation by sRNAs (Bouvier et al., 2008). Further studies also identified other mRNAs which are targeted in this region by RybB (Balbontin et al., 2010; Papenfort et al., 2010), ArcZ (Papenfort et al., 2009), Spot42 (Beisel \& Storz, 2011), and DsrA sRNAs (Lalaouna et al., 2015). 
Table 2. sRNAs that bind within the first $100 \mathrm{nt}$ of the mRNA coding sequence.

\begin{tabular}{|c|c|c|c|c|c|}
\hline sRNA & $\begin{array}{l}\text { mRNA } \\
\text { (bacterial species) }\end{array}$ & $\begin{array}{l}\text { Hfq binds to } \\
\text { sRNA/ mRNA }\end{array}$ & $\begin{array}{l}\text { sRNA binding } \\
\text { site }\end{array}$ & Hfq's role & References \\
\hline RybB & $\begin{array}{l}\text { ompA } \\
\text { (S. Typhimurium) }\end{array}$ & $+/+$ & $+21-+32$ & stabilizes RybB & $\begin{array}{l}\text { (Vytvytska et al., 2000; Papenfort et } \\
\text { al., 2006; Papenfort et al., 2010) }\end{array}$ \\
\hline SgrS & $\begin{array}{l}\operatorname{man} X \\
(E . \text { coli) }\end{array}$ & $+/+$ & $+24-+37$ & stabilizes SgrS & $\begin{array}{l}\text { (Morita et al., 2005; Rice \& Vander- } \\
\text { pool, 2011) }\end{array}$ \\
\hline MgrR & $\begin{array}{l}\text { soxs } \\
\text { (E. coli) }\end{array}$ & $+/+$ & $+29-+44$ & $\begin{array}{l}\text { stabilizes MgrR, necessary for } \\
\text { MgrR-dependent soxS repres- } \\
\text { sion }\end{array}$ & $\begin{array}{l}\text { (Moon and Gottesman 2009; Lee } \\
\text { and Gottesman 2016; Melamed et } \\
\text { al., 2016) }\end{array}$ \\
\hline SdsR & $\begin{array}{l}\text { ompD } \\
\text { (S. Typhimurium) }\end{array}$ & $+/+$ & $+39-+51$ & accelerates SdsR annealing & $\begin{array}{l}\text { (Frohlich et al., 2012; Wroblewska } \\
\text { \& Olejniczak, 2016) }\end{array}$ \\
\hline RybB & $\begin{array}{l}\text { fadL } \\
\text { (S. Typhimurium) }\end{array}$ & $+/+$ & $+43-+50$ & $\begin{array}{l}\text { stabilizes RybB, } \\
\text { accelerates RybB annealing }\end{array}$ & $\begin{array}{l}\text { (Papenfort et al., 2006; Papenfort et } \\
\text { al., 2010; Groszewska et al., 2016) }\end{array}$ \\
\hline SgrS & $\begin{array}{l}\text { purR } \\
\text { (E. coli) }\end{array}$ & $+/+$ & $+49-+67$ & $\begin{array}{l}\text { stabilizes SgrS, } \\
\text { SgrS recruits Hfq to translation } \\
\text { initiation region }\end{array}$ & $\begin{array}{l}\text { (Morita et al., 2005; Bobrovskyy \& } \\
\text { Vanderpool, 2016) }\end{array}$ \\
\hline $\mathrm{MicC}$ & $\begin{array}{l}\text { ompD } \\
\text { (S. Typhimurium) }\end{array}$ & $+/+$ & $+67-+78$ & $\begin{array}{l}\text { stabilizes MicC, accelerates } \\
\text { MicC annealing }\end{array}$ & $\begin{array}{l}\text { (Pfeiffer et al., 2009; Wroblewska \& } \\
\text { Olejniczak, 2016) }\end{array}$ \\
\hline Spot42 & $\begin{array}{l}i c d \\
(E . \text { coli) }\end{array}$ & $+/+$ & $+75-+86$ & stabilizes Spot42 & $\begin{array}{l}\text { (Moller et al., 2002b; Wright et al., } \\
\text { 2013; Melamed et al., 2016) }\end{array}$ \\
\hline Spot42 & $\begin{array}{l}\text { gdhA } \\
(\text { E. coli) }\end{array}$ & $+/+$ & $+80-+94$ & stabilizes Spot42 & $\begin{array}{l}\text { (Moller et al., 2002b; Wright et al., } \\
\text { 2013; Melamed et al., 2016) }\end{array}$ \\
\hline OxyS & $\begin{array}{l}\text { fhlA } \\
\text { (E. coli) }\end{array}$ & $+/+$ & $\begin{array}{l}-9--15 \\
+20-+28\end{array}$ & $\begin{array}{l}\text { affects OxyS stability, accelera- } \\
\text { tes OxyS annealing }\end{array}$ & $\begin{array}{l}\text { (Argaman \& Altuvia, 2000; Zhang } \\
\text { et al., 2002; Salim \& Feig, 2010; } \\
\text { Henderson et al., 2013) }\end{array}$ \\
\hline MicF & $\begin{array}{l}\text { IpxR } \\
\text { (S. Typhimurium) }\end{array}$ & $+/$ n.d. & $\begin{array}{l}-11--3 \\
+70-+104\end{array}$ & $\begin{array}{l}\text { stabilizes MicF, facilitates MicF } \\
\text { annealing }\end{array}$ & $\begin{array}{l}\text { (Urban \& Vogel, 2007; Corcoran et } \\
\text { al., 2012) }\end{array}$ \\
\hline
\end{tabular}

n.d. - no data

The fact that MicL represses translation by binding at +16 to +28 of the lpp coding sequence (Guo et al., 2014) suggests that sRNAs that bind in the region immediately adjacent to the five-codon window could also interfere with the translation initiation, presumably through a steric effect of the remaining sRNA structure.

Besides repression of translation initiation, the sRNA binding in the five-codon window can also lead to mRNA decay. Experiments with untranslated mutants of the $h p$ mRNA indicated that the role of MicL sRNA was to repress $l p p$ mRNA translation, and that the observed mRNA decay was the result of the interrupted translation (Guo et al., 2014). Similarly, binding of the DsrA sRNA to the sequence immediately downstream of the AUG start codon of hns mRNA induced translation repression, which was shown by using in vitro translation assays (Lalaouna et al., 2015). In this case, binding of DsrA was followed by the cleavage of hns mRNA at +131 of the coding sequence, which was dependent on RNase $\mathrm{E}$ and the degradosome (Lalaouna et al., 2015). These data suggest that the primary effect of sRNA binding in the five-codon window and the adjacent area is the repression of translation initiation, while the following mRNA decay could result from the lack of mRNA protection by the ribosome when translation is stopped.

Hfq facilitates pairing of the RybB sRNA to the ompD mRNA (Wroblewska \& Olejniczak, 2016). Repression of this mRNA's translation is induced by RybB binding at +10 to +26 of its coding sequence (Bouvier et al., 2008). Experiments using purified Hfq and RNAs had shown that $\mathrm{Hfq}$ bound both RNAs and increased the rate of their annealing (Wroblewska \& Olejniczak, 2016). A study using short complementary fragments of RybB and ompD mRNA suggested that Hfq rearranged the structures of both interacting RNAs, which facilitated their pairing. Moreover, $\mathrm{Hfq}$ mutagenesis experiments indicated that
Hfq was binding RybB by its proximal face and the opposite distal face was used to interact with ompD mRNA (Wroblewska \& Olejniczak, 2016). This mode of Hfq binding to the interacting RNAs is consistent with the model proposed by previous studies on the role of Hfq in RybB interactions with ompN mRNA (Sauer \& Weichenrieder, 2011; Sauer et al., 2012). Overall, these data suggest that $\mathrm{Hfq}$ facilitates annealing of RybB to the five-codon window of the regulated mRNAs by binding to both interacting RNAs and rearranging their structures.

Besides its role in annealing of sRNAs to the five-codon window, Hfq also contributes to the stability of sRNAs and the decay of their mRNA targets. For example, Hfq protects MicL sRNA from degradation, which enables this sRNA to repress the lpp translation (Guo et al., 2014). Hfq is also necessary for regulation exerted by several other sRNAs targeting the five-codon window, such as Spot42 binding to $x y / F$ and $s t h A$ mRNAs (Beisel \& Storz, 2011), and ArcZ binding to tpx (Papenfort et al., 2009). Although in these cases a precise role of Hfq in the exerted regulation has not been investigated. it seems likely that it could also involve protecting the sRNAs from degradation by cellular ribonucleases. Moreover, Hfq can also participate in the degradosome recruitment to mRNA (Ikeda et al., 2011), which ensures the irreversibility of the sRNA mediated translation repression. Consistently, Hfq was necessary for repression of the hns mRNA translation which is partly dependent on the cleavage of this mRNA by RNase E (Lalaouna et al., 2015).

\section{REGULATION BY SRNAs BINDING DEEPLY IN THE CODING SEQUENCE}

Beyond the footprint of the initiating ribosome, functional sRNA binding sites were identified in the re- 
Table 3. sRNAs that bind deeply in the mRNA coding sequence.

\begin{tabular}{|c|c|c|c|c|c|}
\hline sRNA & $\begin{array}{l}\text { mRNA } \\
\text { (bacterial species) }\end{array}$ & $\begin{array}{l}\text { Hfq binds to } \\
\text { sRNA/ mRNA }\end{array}$ & sRNA binding site & Hfq's role & References \\
\hline SR1 & $\begin{array}{l}\text { ahrC } \\
\text { (B. subtilis) }\end{array}$ & $+/+$ & $\begin{array}{l}\text { multiple predict- } \\
\text { ed sites at }+80 \text { to } \\
+325\end{array}$ & $\begin{array}{l}\text { Hfq affects } a h r C \text { mRNA transla- } \\
\text { tion in vivo }\end{array}$ & $\begin{array}{l}\text { (Heidrich et al., 2006; Heidrich } \\
\text { et al., 2007) }\end{array}$ \\
\hline DsrA & $\begin{array}{l}r b s D \\
\text { (E. coli) }\end{array}$ & $+/+$ & $+298-+313$ & $\begin{array}{l}\text { stabilizes DsrA, } \\
\text { facilitates DsrA annealing }\end{array}$ & $\begin{array}{l}\text { (Sledjeski et al., 2001; Lalaouna } \\
\text { et al., 2015; Melamed et al., } \\
\text { 2016) }\end{array}$ \\
\hline SdsR & $\begin{array}{l}\text { muts } \\
\text { (E. coli) }\end{array}$ & $+/+$ & $+1385-+1409$ & $\begin{array}{l}\text { necessary for SdsR-dependent } \\
\text { repression of MutS translation }\end{array}$ & $\begin{array}{l}\text { (Tsui et al., 1997; Gutierrez et al., } \\
\text { 2013; Melamed et al., 2016) }\end{array}$ \\
\hline SgrS & $\begin{array}{l}\text { yigL } \\
\text { (S. Typhimurium) }\end{array}$ & $+/$ n.d. & $\begin{array}{l}+935-+955 \text { of } \\
\text { pldB }\end{array}$ & $\begin{array}{l}\text { stabilizes SgrS, } \\
\text { activation of yigL is dependent } \\
\text { on } \mathrm{Hfq}\end{array}$ & $\begin{array}{l}\text { (Morita et al., 2005; Papenfort et } \\
\text { al., 2013) }\end{array}$ \\
\hline
\end{tabular}

gions ranging from just outside of the five-codon window region to as far as $1400 \mathrm{nt}$ in the coding sequence (Frohlich et al., 2012; Gutierrez et al., 2013) (Table 2, 3). The majority of these sRNAs bind within the first 100 nucleotides of the coding sequence. This group includes SdsR and MicC sRNAs binding to the ompD mRNA (Pfeiffer et al., 2007; Pfeiffer et al., 2009; Frohlich et al., 2012), RybB sRNA binding to omp $A$ and fadL mRNAs (Papenfort et al., 2010), MicF binding to $l p x R$ mRNA (Corcoran et al., 2012; Holmqvist et al., 2012), MgrR binding to soxS mRNA (Lee \& Gottesman, 2016), SgrS binding to manX mRNA (Rice \& Vanderpool, 2011) and to purR mRNA (Bobrovskyy \& Vanderpool, 2016), and others (Table 2). However, a few sRNAs bind even further downstream in the coding sequence (Table 3). Among them, DsrA sRNA recognizes the $r b s D$ mRNA at +298 to +313 (Lalaouna et al., 2015), and SdsR binds to the mutS mRNA at +1385 to +1409 (Gutierrez et al., 2013).

Even sRNAs binding outside of the footprint of the initiation ribosome can affect the initiation step of translation. Repression of the manX mRNA translation by SgrS binding at +24 to +37 of its coding sequence was not dependent on the mRNA degradation, which suggested that the primary effect of the sRNA binding was translation inhibition (Rice \& Vanderpool, 2011). In a different example, binding of the SR1 sRNA to the coding sequence of $a b r C$ mRNA from Bacillus subtilis resulted in translation repression, which was mediated by the mRNA structure rearrangements (Heidrich et al., 2007). Another mechanism was proposed for control of the purR mRNA translation by the SgrS sRNA. Binding of this sRNA beyond $40 \mathrm{nt}$ in the coding sequence resulted in the recruitment of Hfq to the translation initiation region, where it directly interfered with translation (Bobrovskyy \& Vanderpool 2016). Additionally, secondary sRNA binding sites in the coding sequence could enhance the effect of primary binding sites in the ribosome binding region, as it was observed in the regulation of fhl $A$ and $h x \mathrm{R}$ mRNAs by OxyS and MicF sRNAs, respectively (Argaman \& Altuvia, 2000; Corcoran et al., 2012). These data suggest that sRNAs that bind deeply in the coding sequence can indirectly affect the mRNA translation initiation.

Translation repression by sRNAs targeting the mRNA coding sequence could also result from sRNA-induced mRNA degradation, as it was proposed for the MicC dependent regulation of the ompD mRNA (Pfeiffer et al., 2009; Wagner, 2009). RNase $\mathrm{E}$ is a major bacterial enzyme involved in RNA decay. It can access its RNA substrates either via internal AU-rich binding sites or, more efficiently, through interaction with the 5'-terminal monophosphate groups (Richards \& Belasco 2016). It has been proposed that the MicC sRNA, by binding to the ompD mRNA, recruits RNase $\mathrm{E}$ to induce rapid mRNA degradation (Pfeiffer et al., 2009; Bandyra et al., 2012). The mRNA decay dependent on RNase $E$ has also been reported as a result of the SdsR binding to ompD (Frohlich et al., 2012), MicF binding to $l p x R$ (Corcoran et al., 2012), and RybB binding to omp $A$ and fadL mRNA (Papenfort et al., 2010). However, sRNA binding can also activate translation by interfering with RNase E-dependent mRNA decay. For example, RNase E-dependent cleavage of the pldB mRNA enables the SgrS sRNA binding to the 3 ' end of pldB mRNA coding sequence, which in turn protects this bicistronic transcript from further decay, thus enabling continued translation of the downstream yigL cistron (Papenfort et al., 2013). It is worth noting that RNase $\mathrm{E}$ is not the only ribonuclease involved in the decay of sRNA repressed transcripts (Saramago et al., 2014). For example, although RNase $\mathrm{E}$ is required to release $r b s \mathrm{D}$ from polycistronic mRNA, it is not sufficient to degrade this mRNA, and it was proposed that an alternative RNase could be important for the rbsD decay (Lalaouna et al., 2015).

A frequent theme in translation regulation by sRNAs that bind in the coding sequence is the important role of the mRNA structure rearrangements. For example, the IpxR mRNA structure rearrangement by the MicF sRNA affects its stability by exposing a region containing nucleotides +A82 and +U83 to the RNase E cleavage (Corcoran et al., 2012). Similarly, the rbsD mRNA structure rearrangement upstream of the DsrA sRNA binding site promotes a rapid degradation of this transcript (Lalaouna et al., 2015). In another example, rearrangement of the ompD mRNA structure by the MicC sRNA results in the increased conformational flexibility of a region downstream of the sRNA binding site (Wroblewska \& Olejniczak, 2016). Finally, rearrangement of the $a b r C$ structure upon SR1 sRNA binding was implicated in the repression of translation initiation (Heidrich et al., 2007).

Hfq binds MicC sRNA with sub-nanomolar affinity and accelerates its annealing to the ompD mRNA coding sequence (Wroblewska \& Olejniczak, 2016). It was found that the role of $\mathrm{Hfq}$ was mainly to overcome the energetic barrier of the MicC sRNA structure, in agree- 
ment with the fact that the MicC binding site in ompD was located in a partly unstructured region, likely accessible to sRNA pairing. It was also proposed that the long AU-rich sequence in the 5'-UTR of ompD mRNA served as the Hfq binding site essential for the MicC sRNA annealing to the coding sequence (Wroblewska \& Olejniczak, 2016). Comparison of the Hfq-dependent annealing of the RybB and MicC sRNAs to the ompD mRNA, and the DsrA sRNA annealing to the rpoS mRNA, suggests that the Hfq contributions are individually tuned, depending on the structures of the interacting RNAs, to achieve their accelerated annealing (Soper \& Woodson, 2008; Soper et al., 2011; Wroblewska \& Olejniczak, 2016).

The Hfq protein also contributes to the translation regulation by other sRNAs binding deeply in the coding sequence. Hfq stabilizes the MicF sRNA, facilitates this sRNA's binding to the $/ p x \mathrm{R}$ mRNA, and is required for MicF-dependent regulation of $l p x R$ expression (Urban \& Vogel, 2007; Corcoran et al., 2012). Lack of Hfq prevents DsrA dependent repression of $r b s D$, probably because of the lowered DsrA stability (Sledjeski et al., 2001; Lalaouna et al., 2015). In another example, the mismatchrepair activity of MutS is restored in $\Delta h f q$ mutant, which suggests the involvement of Hfq in SdsR-mutS interactions (Tsui et al., 1997; Gutierrez et al., 2013). Hfq also contributed to activation of the yigL mRNA expression (Papenfort et al., 2013). Moreover, Hfq is directly responsible for efficient inhibition of purR translation after recruitment by SgrS (Bobrovskyy \& Vanderpool, 2016). As recent high-throughput studies discovered numerous binding sites of Hfq alone in the coding sequences, as well as new binding sites of Hfq-bound sRNAs, it is likely that further research will widely expand our knowledge on the mechanisms used by Hfq in the regulation of translation (Tree et al., 2014; Holmqvist et al., 2016; Melamed et al., 2016).

\section{CONCLUSIONS}

Recent data has shown that the mRNA coding sequence is an important target for small regulatory RNAs in bacteria. The major mechanism of action of those sRNAs, which bind within the first five codons of an mRNA, is inhibition of the translation initiation step. When sRNAs bind outside of the footprint of the initiating ribosome, their action typically involves mRNA degradation, although there are also examples of the primary effect on translation inhibition. The data presented in this review indicate that $\mathrm{Hfq}$ can contribute to the regulation exerted by binding to the coding sequence in different ways. It protects the sRNAs from degradation, accelerates their annealing to mRNAs, and participates in recruiting RNases to the mRNAs that are repressed. Hfq may also induce rearrangements of the RNA structure, which is determined by individual structural features of the interacting RNAs. However, Hfq can also directly interfere with translation after it is recruited by a regulatory RNA. As the recent studies identified numerous new Hfq binding sites in the coding sequences of $\mathrm{mR}$ NAs, it is likely that new Hfq contributions to the complex interactions regulating bacterial metabolism will be revealed.

\section{Financial acknowledgements}

This work was supported by the KNOW RNA Research Centre in Poznań (No. 01/KNOW2/2014), the National Science Centre in Poland (No. 2014/15/B/
NZ1/03330) and the Foundation for Polish Science No. TEAM/2011-8/5) co-financed by the European Union Regional Development Fund within the framework of the Operational Program Innovative Economy.

\section{REFERENCES}

Andrade JM, Pobre V, Matos AM, Arraiano CM (2012) The crucial role of PNPase in the degradation of small RNAs that are not associated with Hfq. RNA 18: 844-855. doi: 10.1261/rna.029413.111

Argaman L, Altuvia S (2000) fhlA repression by OxyS RNA: kissing complex formation at two sites results in a stable antisensetarget RNA complex. J Mol Biol 300: 1101-1112. doi: 10.1006/ jmbi.2000.3942

Balbontin R, Fiorini F, Figueroa-Bossi N, Casadesus J, Bossi L (2010) Recognition of heptameric seed sequence underlies multi-target regulation by RybB small RNA in Salmonella enterica. Mol Microbiol 78: 380-394. doi: 10.1111/j.1365-2958.2010.07342.x

Bandyra KJ, Said N, Pfeiffer V, Gorna MW, Vogel J, Luisi BF (2012) The seed region of a small RNA drives the controlled destruction of the target mRNA by the endoribonuclease RNase E. Mol Cell 47: 943-953. doi: 10.1016/j.molcel.2012.07.015

Beisel CL, Storz G (2011) The base-pairing RNA spot 42 participates in a multioutput feedforward loop to help enact catabolite repression in Escherichia coli. Mol Cell 41: 286-297. doi: 10.1016/j.molcel.2010.12.027

Bobrovskyy M, Vanderpool CK (2016) Diverse mechanisms of posttranscriptional repression by the small RNA regulator of glucose-phosphate stress. Mol Microbiol 99: 254-273. doi: 10.1111/ mmi.13230

Bouvier M, Sharma CM, Mika F, Nierhaus KH, Vogel J (2008) Small RNA binding to 5' mRNA coding region inhibits translational initiation. Mol Cell 32: 827-837. doi: 10.1016/j.molcel.2008.10.027

Cech GM, Pakula B, Kamrowska D, Wegrzyn G, Arluison V, Szalewska-Palasz A (2014) Hfq protein deficiency in Escherichia coli affects ColE1-like but not lambda plasmid DNA replication. Plasmid 73: 10-15. doi: 10.1016/j.plasmid.2014.04.005

Chao Y, Vogel J (2010) The role of Hfq in bacterial pathogens. Curr Opin Microbiol 13: 24-33. 10.1016/j.mib.2010.01.001

Chao Y, Vogel J (2016) A 3' UTR-Derived Small RNA provides the regulatory noncoding arm of the inner membrane stress response. Mol Cell 61: 352-363. doi: 10.1016/j.molcel.2015.12.023

Corcoran CP, Podkaminski D, Papenfort K, Urban JH, Hinton JC, Vogel J (2012) Superfolder GFP reporters validate diverse new mRNA targets of the classic porin regulator, MicF RNA. Mol Microbiol 84: 428-445. doi: 10.1111/j.1365-2958.2012.08031.x

de Haseth PL, Uhlenbeck OC (1980) Interaction of Escherichia coli host factor protein with oligoriboadenylates. Biochemistry 19: 6138-6146. doi: $10.1021 / \mathrm{bi00567a029}$

Desnoyers G, Masse E (2012) Noncanonical repression of translation initiation through small RNA recruitment of the RNA chaperone Hfq. Genes Dev 26: 726-739. doi: 10.1101/gad.182493.111

Ellis MJ, Trussler RS, Haniford DB (2015) Hfq binds directly to the ribosome-binding site of IS10 transposase mRNA to inhibit translation. Mol Microbiol 96: 633-650. doi: 10.1111/mmi.12961

Fender A, Elf J, Hampel K, Zimmermann B, Wagner EG (2010) RNAs actively cycle on the Sm-like protein Hfq. Genes Dev 24: 2621-2626. doi: 10.1101/gad.591310

Fontaine F, Gasiorowski E, Gracia C, Ballouche M, Caillet J, Marchais A, Hajnsdorf E (2016) The small RNA SraG participates in PNPase homeostasis. RNA 22: 1560-1573. doi: 10.1261/rna.055236.115

Frohlich KS, Haneke K, Papenfort K, Vogel J (2016) The target spectrum of SdsR small RNA in Salmonella. Nucleic Acids Res. doi: 10.1093/nar/gkw632

Frohlich KS, Papenfort K, Berger AA, Vogel J (2012) A conserved RpoS-dependent small RNA controls the synthesis of major porin OmpD. Nucleic Acids Res 40: 3623-3640. doi: 10.1093/nar/gkr1156

Geissmann TA, Touati D (2004) Hfq, a new chaperoning role: binding to messenger RNA determines access for small RNA regulator. EMBO J 23: 396-405. doi: 10.1038/sj.emboj.7600058

Groszewska A, Wroblewska Z, Olejniczak M (2016) The structure of fadL mRNA and its interactions with RybB sRNA. Acta Biochim Pol 63: 853-840. https://doi.org/10.18388/abp.2016_1361

Guo MS, Updegrove TB, Gogol EB, Shabalina SA, Gross CA, Storz G (2014) MicL, a new sigmaE-dependent sRNA, combats envelope stress by repressing synthesis of Lpp, the major outer membrane lipoprotein. Genes Dev 28: 1620-1634. 10.1101/gad.243485.114

Gutierrez A, Laureti L, Crussard S, Abida H, Rodriguez-Rojas A, Blazquez J, Baharoglu Z, Mazel D, Darfeuille F, Vogel J et al., (2013) beta-Lactam antibiotics promote bacterial mutagenesis via an RpoS-mediated reduction in replication fidelity. Nat Commun 4: 1610. $10.1038 /$ ncomms 2607

Hao Y, Updegrove TB, Livingston NN, Storz G (2016) Protection against deleterious nitrogen compounds: role of sigmaS-depend- 
ent small RNAs encoded adjacent to sdiA. Nucleic Acids Res. doi: $10.1093 / \mathrm{nar} / \mathrm{gkw} 404$

Heidrich N, Chinali A, Gerth U, Brantl S (2006) The small untranslated RNA SR1 from the Bacillus subtilis genome is involved in the regulation of arginine catabolism. Mol Microbiol 62: 520-536. doi: 10.1111/j.1365-2958.2006.05384.x

Heidrich N, Moll I, Brantl S (2007) In vitro analysis of the interaction between the small RNA SR1 and its primary target ahrC mRNA. Nucleic Acids Res 35: 4331-4346. doi: 10.1093/nar/gkm439

Henderson CA, Vincent HA, Casamento A, Stone CM, Phillips JO, Cary PD, Sobott F, Gowers DM, Taylor JE, Callaghan AJ (2013) Hfq binding changes the structure of Escherichia coli small noncoding RNAs OxyS and RprA, which are involved in the riboregulation of rpoS. RNA 19: 1089-1104. doi: 10.1261/rna.034595.112

Holmqvist E, Unoson C, Reimegard J, Wagner EG (2012) A mixed double negative feedback loop between the sRNA MicF and the global regulator Lrp. Mol Microbiol 84: 414-427. doi: 10.1111/j.13652958.2012.07994.x

Holmqvist E, Wright PR, Li L, Bischler T, Barquist L, Reinhardt R, Backofen R, Vogel J (2016) Global RNA recognition patterns of post-transcriptional regulators $\mathrm{Hfq}$ and CsrA revealed by UV crosslinking in vivo. EMBO J 35: 991-1011. doi: 10.15252/ embj. 201593360

Huttenhofer A, Noller HF (1994) Footprinting mRNA-ribosome complexes with chemical probes. EMBO J 13: 3892-3901. http://www. ncbi.nlm.nih.gov/pubmed/8070416

Ikeda Y, Yagi M, Morita T, Aiba H (2011) Hfq binding at RhlB-recognition region of $\mathrm{RNase} E$ is crucial for the rapid degradation of target mRNAs mediated by sRNAs in Escherichia coli. Mol Microbiol 79: 419-432. doi: 10.1111/j.1365-2958.2010.07454.x

Jorgensen MG, Thomason MK, Havelund J, Valentin-Hansen P, Storz G (2013) Dual function of the McaS small RNA in controlling biofilm formation. Genes Dev 27: 1132-1145. doi: 10.1101/ gad.214734.113

Kakoschke TK, Kakoschke SC, Zeuzem C, Bouabe H, Adler K, Heesemann J, Rossier O (2016) The RNA chaperone Hfq is essential for virulence and modulates the expression of four adhesins in Yersinia enterocolitica. Sci Rep 6: 29275. doi: 10.1038/srep29275

Lalaouna D, Morissette A, Carrier MC, Masse E (2015) DsrA regulatory RNA represses both hns and rbsD mRNAs through distinct mechanisms in Escherichia coli. Mol Microbiol 98: 357-369. doi: 10.1111/mmi.13129

Lease RA, Woodson SA (2004) Cycling of the Sm-like protein Hfq on the DsrA small regulatory RNA. J Mol Biol 344: 1211-1223. doi: 10.1016/j.jmb.2004.10.006

Lee HJ, Gottesman S (2016) sRNA roles in regulating transcriptional regulators: Lrp and SoxS regulation by sRNAs. Nucleic Acids Res 44: 6907-6923. doi: 10.1093/nar/gkw358

Link TM, Valentin-Hansen P, Brennan RG (2009) Structure of Escherichia coli Hfq bound to polyriboadenylate RNA. Proc Natl Acad Sci U S A 106: 19292-19297. doi: 10.1073/pnas.0908744106

Malecka EM, Strozecka J, Sobanska D, Olejniczak M (2015) Structure of bacterial regulatory RNAs determines their performance in competition for the chaperone protein Hfq. Biochemistry 54: 1157-1170. doi: $10.1021 /$ bi500741d

Melamed S, Peer A, Faigenbaum-Romm R, Gatt YE, Reiss N, Bar A, Altuvia Y, Argaman L, Margalit H (2016) Global mapping of small RNA-target interactions in bacteria. Mol Cell 63: 884-897. 10.1016/j. molcel.2016.07.026

Mikulecky PJ, Kaw MK, Brescia CC, Takach JC, Sledjeski DD, Feig AL (2004) Escherichia coli Hfq has distinct interaction surfaces for DsrA, rpoS and poly(A) RNAs. Nat Struct Mol Biol 11: 1206-1214. doi: $10.1038 / \mathrm{nsmb} 858$

Moller T, Franch T, Hojrup P, Keene DR, Bachinger HP, Brennan RG, Valentin-Hansen P (2002a) Hfq: a bacterial Sm-like protein that mediates RNA-RNA interaction. Mol Cell 9: 23-30. http:// dx.doi.org/10.1016/S1097-2765(01)00436-1

Moller T, Franch T, Udesen C, Gerdes K, Valentin-Hansen P (2002b) Spot 42 RNA mediates discoordinate expression of the E. coli galactose operon. Genes Dev 16: 1696-1706. doi: 10.1101/gad.231702

Moon K, Gottesman S (2009) A PhoQ/P-regulated small RNA regulates sensitivity of Escherichia coli to antimicrobial peptides. Mol Microbiol 74: 1314-1330. doi: 10.1111/j.1365-2958.2009.06944.x

Morita T, Maki K, Aiba H (2005) RNase E-based ribonucleoprotein complexes: mechanical basis of mRNA destabilization mediated by bacterial noncoding RNAs. Genes Dev 19: 2176-2186. doi: 10.1101/ gad. 1330405

Morita T, Ueda M, Kubo K, Aiba H (2015) Insights into transcription termination of Hfq-binding sRNAs of Escherichia coli and characterization of readthrough products. RNA 21: 1490-1501. doi: 10.1261/ rna.051870.115

Olejniczak M (2011) Despite similar binding to the Hfq protein regulatory RNAs widely differ in their competition performance. Biochemistry 50: 4427-4440. doi: 10.1021/bi102043f

Otaka H, Ishikawa H, Morita T, Aiba H (2011) PolyU tail of rho-independent terminator of bacterial small RNAs is essential for Hfq action. Proc Natl Acad Sci U S A 108: 13059-13064. doi: 10.1073/ pnas. 1107050108

Panja S, Santiago-Frangos A, Schu DJ, Gottesman S, Woodson SA (2015) Acidic residues in the Hfq chaperone increase the selectivity of sRNA binding and annealing. J Mol Biol 427: 3491-3500. doi: 10.1016/j.jmb.2015.07.010

Panja S, Schu DJ, Woodson SA (2013) Conserved arginines on the rim of Hfq catalyze base pair formation and exchange. Nucleic Acids Res 41: 7536-7546. doi: 10.1093/nar/gkt521

Papenfort K, Bouvier M, Mika F, Sharma CM, Vogel J (2010) Evidence for an autonomous 5' target recognition domain in an Hfqassociated small RNA. Proc Natl Acad Si U S A 107: 20435-20440. doi: $10.1073 /$ pnas.1009784107

Papenfort K, Espinosa E, Casadesus J, Vogel J (2015) Small RNAbased feedforward loop with AND-gate logic regulates extrachromosomal DNA transfer in Salmonella. Proc Natl Acad Sci U SA 112: E4772-E4781. doi: 10.1073/pnas.1507825112

Papenfort K, Pfeiffer V, Mika F, Lucchini S, Hinton JC, Vogel J (2006) SigmaE-dependent small RNAs of Salmonella respond to membrane stress by accelerating global omp mRNA decay. Mol Microbiol 62: 1674-1688. doi: 10.1111/j.1365-2958.2006.05524.x

Papenfort K, Said N, Welsink T, Lucchini S, Hinton JC, Vogel J (2009) Specific and pleiotropic patterns of mRNA regulation by ArcZ, a conserved, Hfq-dependent small RNA. Mol Microbiol 74: 139-158. doi: $10.1111 / j .1365-2958.2009 .06857 . x$

Papenfort K, Sun Y, Miyakoshi M, Vanderpool CK, Vogel J (2013) Small RNA-mediated activation of sugar phosphatase mRNA regulates glucose homeostasis. Cell 153: 426-437. doi: 10.1016/j. cell.2013.03.003

Papenfort K, Vogel J (2014) Small RNA functions in carbon metabolism and virulence of enteric pathogens. Front Cell Infect Microbiol 4: 91. doi: 10.3389 /fcimb.2014.00091

Parker A, Gottesman S (2016) Small RNA regulation of TolC, the outer membrane component of bacterial multidrug transporters. $J$ Bacteriol 198: 1101-1113. 10.1128/JB.00971-15

Peng Y, Curtis JE, Fang X, Woodson SA (2014a) Structural model of an mRNA in complex with the bacterial chaperone Hfq. Proc Natl Acad Sci U S A 111: 17134-17139. doi: 10.1073/pnas.1410114111

Peng Y, Soper TJ, Woodson SA (2014b) Positional effects of AAN motifs in rpoS regulation by sRNAs and Hfq. J Mol Biol 426: $275-$ 285. doi: $10.1016 /$ j.jmb.2013.08.026

Pfeiffer V, Papenfort K, Lucchini S, Hinton JC, Vogel J (2009) Coding sequence targeting by MicC RNA reveals bacterial mRNA silencing downstream of translational initiation. Nat Struct Mol Biol 16: 840846. doi: $10.1038 / \mathrm{nsmb} .1631$

Pfeiffer V, Sittka A, Tomer R, Tedin K, Brinkmann V, Vogel J (2007) A small non-coding RNA of the invasion gene island (SPI-1) represses outer membrane protein synthesis from the Salmonella core genome. Mol Microbiol 66: 1174-1191. doi: 10.1111/j.13652958.2007.05991.x

Qu X, Wen JD, Lancaster L, Noller HF, Bustamante C, Tinoco I, Jr. (2011) The ribosome uses two active mechanisms to unwind messenger RNA during translation. Nature 475: 118-121. doi: 10.1038/ nature 10126

Rice JB, Vanderpool CK (2011) The small RNA SgrS controls sugarphosphate accumulation by regulating multiple PTS genes. Nucleic Acids Res 39: 3806-3819. doi: 10.1093/nar/gkq1219

Richards J, Belasco JG (2016) Distinct Requirements for 5'-Monophosphate-assisted RNA Cleavage by Escherichia coli RNase E and RNase G. J Biol Chem 291: 5038-5048. doi: 10.1074/jbc.M115.702555

Salim NN, Faner MA, Philip JA, Feig AL (2012) Requirement of upstream Hfq-binding (ARN) $x$ elements in glmS and the Hfq C-terminal region for GlmS upregulation by sRNAs GlmZ and GlmY. Nucleic Acids Res 40: 8021-8032. doi: 10.1093/nar/gks392

Salim NN, Feig AL (2010) An upstream Hfq binding site in the fhlA mRNA leader region facilitates the OxyS-fhlA interaction. PLoS One 5. doi: 10.1371/journal.pone.0013028

Salvail H, Caron MP, Belanger J, Masse E (2013) Antagonistic functions between the RNA chaperone $\mathrm{Hfq}$ and an sRNA regulate sensitivity to the antibiotic colicin. EMBO J 32: 2764-2778. doi: 10.1038/emboj.2013.205

Santiago-Frangos A, Kavita K, Schu DJ, Gottesman S, Woodson SA (2016) C-terminal domain of the RNA chaperone Hfq drives sRNA competition and release of target RNA. Proc Natl Acad Sci USA. doi: $10.1073 /$ pnas.1613053113

Saramago M, Barria C, Dos Santos RF, Silva IJ, Pobre V, Domingues S, Andrade JM, Viegas SC, Arraiano CM (2014) The role of RNases in the regulation of small RNAs. Curr Opin Microbiol 18: 105-115. doi: 10.1016/j.mib.2014.02.009

Sauer E, Schmidt S, Weichenrieder O (2012) Small RNA binding to the lateral surface of $\mathrm{Hfq}$ hexamers and structural rearrangements upon mRNA target recognition. Proc Natl Acad Sci U SA 109: 9396-9401. doi: 10.1073/pnas.1202521109

Sauer E, Weichenrieder O (2011) Structural basis for RNA 3'-end recognition by Hfq. Proc Natl Acad Sci U S A 108: 13065-13070. doi: $10.1073 /$ pnas. 1103420108 
Schu DJ, Zhang A, Gottesman S, Storz G (2015) Alternative HfqsRNA interaction modes dictate alternative mRNA recognition. EMBO J 34: 2557-2573. doi: 10.15252/embj.201591569

Schumacher MA, Pearson RF, Moller T, Valentin-Hansen P, Brennan RG (2002) Structures of the pleiotropic translational regulator $\mathrm{Hfq}$ and an Hfq-RNA complex: a bacterial Sm-like protein. EMBO J 21: 3546-3556. doi: 10.1093/emboj/cdf322

Sittka A, Lucchini S, Papenfort K, Sharma CM, Rolle K, Binnewies T'T, Hinton JC, Vogel J (2008) Deep sequencing analysis of small noncoding RNA and mRNA targets of the global post-transcriptional regulator, Hfq. PLoS Genet 4: e1000163. doi: 10.1371/journal. pgen.1000163

Sittka A, Sharma CM, Rolle K, Vogel J (2009) Deep sequencing of Salmonella RNA associated with heterologous Hfq proteins in vivo reveals small RNAs as a major target class and identifies RNA processing phenotypes. RNA Biol 6: 266-275. http://dx.doi. org/10.4161/rna.6.3.8332

Sledjeski DD, Whitman C, Zhang A (2001) Hfq is necessary for regulation by the untranslated RNA DsrA. J Bacteriol 183: 1997-2005. doi: 10.1128/JB.183.6.1997-2005.2001

Sonnleitner E, Blasi U (2014) Regulation of Hfq by the RNA CrcZ in Pseudomonas aeruginosa carbon catabolite repression. PLoS Genet 10: e1004440. doi: 10.1371/journal.pgen.1004440

Soper T, Mandin P, Majdalani N, Gottesman S, Woodson SA (2010) Positive regulation by small RNAs and the role of Hfq. Proc Natl Acad Sci US A 107: 9602-9607. doi: 10.1073/pnas.1004435107

Soper TJ, Doxzen K, Woodson SA (2011) Major role for mRNA binding and restructuring in sRNA recruitment by Hfq. RNA 17: 1544 1550. doi: $10.1261 /$ rna.2767211

Soper TJ, Woodson SA (2008) The rpoS mRNA leader recruits Hfq to facilitate annealing with DsrA sRNA. RNA 14: 1907-1917. doi: $10.1261 /$ rna.1110608

Takyar S, Hickerson RP, Noller HF (2005) mRNA helicase activity of the ribosome. Cell 120: 49-58. doi: 10.1016/j.cell.2004.11.042

Tree JJ, Granneman S, McAteer SP, Tollervey D, Gally DL (2014) Identification of bacteriophage-encoded anti-sRNAs in pathogenic Escherichia coli. Mol Cell 55: 199-213. doi: 10.1016/j.molcel.2014.05.006

Tsui HC, Feng G, Winkler ME (1997) Negative regulation of mutS and mutH repair gene expression by the $\mathrm{Hfq}$ and RpoS global regulators of Escherichia coli K-12. I Bacteriol 179: 7476-7487. doi: 10.1128/jb.179.23.7476-7487.1997

Updegrove TB, Zhang A, Storz G (2016) Hfq: the flexible RNA matchmaker. Curr Opin Microbiol 30: 133-138. doi: 10.1016/j. mib.2016.02.003

Urban JH, Vogel J (2007) Translational control and target recognition by Escherichia coli small RNAs in vivo. Nucleic Acids Res 35: 10181037. doi: $10.1093 / \mathrm{nar} / \mathrm{gkl} 1040$

Vogel J, Luisi BF (2011) Hfq and its constellation of RNA. Nat Rev Microbiol 9: 578-589. doi: 10.1038/nrmicro2615

Vytvytska O, Moll I, Kaberdin VR, von Gabain A, Blasi U (2000) Hfq (HF1) stimulates ompA mRNA decay by interfering with ribosome binding. Genes Dev 14: 1109-1118. doi: 10.1101/gad.14.9.1109

Wagner EG (2009) Kill the messenger: bacterial antisense RNA promotes mRNA decay. Nat Struct Mol Biol 16: 804-806. doi: 10.1038/ nsmb0809-804

Waters LS, Storz G (2009) Regulatory RNAs in bacteria. Cell 136: 615628. doi: $10.1016 /$ j.cell.2009.01.043

Wright PR, Richter AS, Papenfort K, Mann M, Vogel J, Hess WR, Backofen R, Georg J (2013) Comparative genomics boosts target prediction for bacterial small RNAs. Proc Natl Acad Sci U S A 110: E3487-E3496. doi: 10.1073/pnas.1303248110

Wroblewska Z, Olejniczak M (2016) Hfq assists small RNAs in binding to the coding sequence of ompD mRNA and in rearranging its structure. RNA 22: 979-994. doi: 10.1261/rna.055251.115

Yusupova GZ, Yusupov MM, Cate JH, Noller HF (2001) The path of messenger RNA through the ribosome. Cell 106: 233-241. http:// dx.doi.org/10.1016/S0092-8674(01)00435-4

Zhang A, Schu DJ, Tjaden BC, Storz G, Gottesman S (2013) Mutations in interaction surfaces differentially impact $E$. coli Hfq association with small RNAs and their mRNA targets. J Mol Biol 425: 3678-3697. doi: 10.1016/j.jmb.2013.01.006

Zhang A, Wassarman KM, Ortega J, Steven AC, Storz G (2002) The Sm-like Hfq protein increases OxyS RNA interaction with target mRNAs. Mol Cell 9: 11-22. http://dx.doi.org/10.1016/S10972765(01)00437-3

Zheng A, Panja S, Woodson SA (2016) Arginine patch predicts the RNA annealing activity of Hfq from gram-negative and grampositive bacteria. J Mol Biol 428: 2259-2264. doi: 10.1016/j. jmb.2016.03.027 